\title{
Rethinking Capital's Relations to Nature: From the Production of Nature Thesis to World-Ecological Synthesis
}

\author{
Jay BOLTHOUSE \\ University of Tokyo
}

\begin{abstract}
The geographies of nature literature has revolutionized conceptions of nature in geography. Yet all is not well on the socionatural front. Geographers have focused on the downstream consequences of capital for ecology but neglected modernity's upstream sources, its foundational eco-relations and eco-logic. The production of nature thesis, a foundational statement for geographies of nature, pointed toward historical-theoretical reconstruction of capital-nature relations but stagnated at the stage of thesis. This article argues for moving from the production of nature thesis to world-ecological synthesis through an overview and critique of the world-ecological perspective, an approach pioneered by geographer Jason W. Moore. This perspective represents a great leap forward for rethinking capital's eco-relations and eco-logic, but remains overlooked by many human geographers for at least two reasons, both of which this article aims to remedy. First, a comprehensive overview remains missing. Accordingly, this article first reviews Moore's work, from its historical-geographical foundations, to its theoretical elaborations and its account of present crises and political struggles. Second, the world-ecology perspective has been advanced through a historical materialism somewhat at odds with contemporary human geographer's focus on culture, power and knowledge. My critique suggests that bringing Gramsci's ethico-politically infused historical materialism into worldecology marks a pathway forward for geographies of nature.
\end{abstract}

Key words: world-ecology, commodity frontiers, value-relations, abstract social nature, ethicopolitical

\section{Geographies of Nature: Limits and Prospects}

Geographies of nature - the focus of this special issue - refers to a wide-ranging literature tied together by an urge to replace nature and society dualisms with socionature, an ontology of mutual co-production in which humans and non-humans produce the web of life (Asano and Nakashima 2013). This body of literature has revolutionized conceptions of nature in geography and growing allegiance to the socionatural view among human geographers is to be celebrated. Yet all is not well on the socionatural front. Simply put, the post-Cartesian worldview has proven difficult to translate into analytical strategies and methodological frameworks for understanding the socioecological constitution of capital and modernity. Geographies of nature 
have focused on the downstream consequences of capital for ecology, while neglecting modernity's upstream sources, its foundational eco-relations and eco-logic. Lacking robust world-historical foundations, the socionatural view too easily cracks when faced with ostensibly non-ecological issues such as neoliberalism or financialization. David Harvey's (2014) latest work - Seventeen Contradictions and the End of Capitalism - is illustrative. Only after analyzing fifteen of capital's contradictions does Harvey arrive at the contradictory nature of "capital's relation to nature" (Harvey 2014, 246-263). The problem here is that not foregrounding "capital's relation to nature" as modernity's foundational contradiction - the materio-relational matrix through which all other contradictions unfold - leaves us unable to meet Harvey's apt challenge to "more fully understand how the contradictory unity between capital and nature works" (Harvey 2014, 250). Only by foregrounding the contradictory unity of capital and nature as foundational and world-historical can geographers uncover, and help to sever, the entangled roots of today's economic and ecological crisis. That is the task ahead for geographies of nature.

Unrealized potential for geographies of nature to excavate the foundational and worldhistorical relations of capital and nature is found in one of that literature's foundational statements: the "production of nature" thesis. Smith's (1984) thesis was scandalous. It asked us to see nature - society's other - as socially produced. In retrospect, the production of nature thesis played a crucial part in extending geography's early encounter with Marx to questions of nature, thus placing radical approaches in contention for one of the discipline's traditional cores. The geographies of nature literature abounds with applications and extensions of the production of nature thesis, and geographers continue to consider how to advance its theoretical claims and political purchase. In so doing, there is, however, a great need to honestly assess that thesis' limits. We must remember that while Smith's account of the production of nature was pitched as world-historical, it was but a sketch, a 'first-cut' based on theoretical abstraction, not historical revision. As Labban argues, Smith "confronted the dialectical tension between capitalism as theoretical abstraction and capitalism as concrete historical process through a logico-historical theorisation of the production of nature" in which "the uneven geography of contemporary capitalism is derived from the unfolding of the abstract laws and tendencies of capital as theorised by Marx, scarcely shaped by concrete historical processes" (Labban 2011, 254). Thirty years later, the problem is not with Smith's path-breaking account, but rather that the "historical dialogue" (Smith 1984, 6) it proposed between the history and theory of nature-capital relations remains far too muted.

Recognizing the above limitations, Ekers and Loftus (2012) provide a critique aimed at "revitalizing" the production of nature thesis. They argue that moving "from the abstract to the concrete and adequately historicizing the production of nature" is the crucial task for advancing Smith's project today (Ekers and Loftus 2012, 239). To push towards concrete historicization, the authors turn to Gramsci, a move proving increasingly popular and productive for geographies of nature (Ekers et al. 2013). They find in Gramsci's work a demand for an "absolute historicism" of the "ensemble of relations" shaping the production of nature that they argue can critically enhance accounts of the production of nature (Ekers and Loftus 2012, 244-249). While this is a highly constructive critique, my sense is that this blueprint for revitalization falls short of reviving the critical spirit that animated either Smith or Gramsci. The authors call primarily for better application of the production of nature thesis rather than theoretical reconstruction or synthesis. The problem here is that, as Labban $(2011,254)$ argues, the production of nature thesis "needs to be historicised further, not by 'applying' the theory in more empirical case studies, 
but through a critical reconstruction of the theoretical argument itself". That is, revitalization of the production of nature thesis demands not more case studies further historicized but an all together improved means of historicization, a historical-theoretical framework for theorizing capital's world-historical relation to nature that connects the cases and the whole. Smith (2008, 2011) certainly felt that revitalizing the production of nature thesis was a world-historical task, repeatedly asserting in later commentaries that identifying the process whereby nature was cleaved from society in the early modern period was critical to advancing his initial project. As regards Gramsci, it is troubling that Marx's value theory is absent from Ekers and Loftus' (2012) appeals to absolute historicism, when value theory was for Gramsci the "unitary center" of historical materialism and the headwaters of hegemony (Wainwright 2010a). A Gramscian approach marks a pathway forward, but requires moving from the production of nature thesis to world-ecological synthesis.

Fortunately, over the past decade, a world-historical framework for interrogating the production of nature has emerged under the banner of the 'world-ecological perspective', a knowledge frontier pioneered and ably advanced by geographer Jason W. Moore. Philosophically speaking, there is little difference between the world-ecology perspective and the geographies of nature literature. They share a broadly socionatural worldview. The difference is that worldecology asks us to put our post-Cartesian worldview to work on the crucible of world-historical transformation. As Moore (2014a, 6) argues, “[T] he Achilles' Heel of the post-Cartesian critique has been historical analysis, resulting in a disjuncture between the 'production of nature' as theoretical construct and world-historical process. Without a sufficient historical grounding, the critique of Nature/Society dualism tends to stumble on the terrain of world history." In the broadest of terms it is possible to describe the world-ecology perspective as a field of research concerned with investigating, explaining and overcoming the relations of the Capitalocene "the historical era shaped by relations privileging the endless accumulation of capital" (Moore 2014a, 5). It is an approach in which "[T] he modern world-system becomes ... a capitalist worldecology: a civilization that joins the accumulation of capital, the pursuit of power, and the production of nature as an organic whole" (Moore 2014a, 11). It takes us from the production of nature as thesis to world-ecological synthesis, the key move for advancing our geographies of nature.

The following contribution to this special issue's theme - rethinking geographies of nature takes up that urgent task through a comprehensive overview and critique of the world-ecology perspective. As I will demonstrate, this perspective represents a great leap forward for rethinking capital's relations to nature, specifically its eco-relations and its eco-logic. However, world-ecology remains overlooked and under-utilized by many human geographers for at least two reasons, both of which this article aims to remedy. First, a brief yet comprehensive statement remains absent. Accordingly, this article provides an overview and reflective summary of the corpus of geographer Jason W. Moore, the pioneer and leading proponent of the worldecology perspective. Moore has published broadly but has not published any comprehensive statement, nor has his work has received any critical summary. The value-added of this paper is to offer an intellectual history of the emergence and advance of the world-ecological perspective. What I aim to highlight, in particular, is the way in which Moore's work radically advances our framework for interrogating the production of nature by initiating the longawaited dialogue between the historical-geography of capital's ecological relations and a regrounded theory of capital's eco-logic. The second issue that this article aims to remedy 
concerns the type of historical materialism that animates world-ecological research. For the most part, the world-ecology perspective has been advanced through a historical materialism at odds with contemporary human geographer's focus on culture, power and knowledge. Moore has begun to remedy this by placing renewed emphasis on the technics through which nature is rendered abstract and appropriable. However there is a real need to supplement this technical moment with further attention to the moral politics through which natures are made. My critique suggests that combining Gramsci's ethico-politically infused historical materialism and world-ecology marks the crucial pathway forward for geographies of nature.

\section{Historical Foundations: From Feudalism to Capitalism via the Commodity Frontier}

The world-ecology perspective emerges from Moore's (2002; 2003; 2007; 2009; 2010a; 2010b; 2010c; 2010d) analysis of feudal crisis and capitalist transition. While these issues have been long debated, Moore (2003) draws on the overlooked eco-historical content of Wallerstein's (1974) The Modern World-System to push them onto the terrain of political ecology. It is impossible to do justice here to this body of research. My aim is to illustrate how Moore's return to foundational questions performs the crucial task of shifting our attention from capital's ecological consequences to its constitutive ecological relations.

\section{Feudalism's Socioecological Crisis and the Becoming Necessity of an External Fix}

For many geographers, the crisis of feudalism in the long fourteenth century (1300-1450) will seem far removed from present concerns. Moore (2002; 2003; 2007) convincingly argues, however, that feudalism's socioecological contradictions are key to understanding the source of capital's contradictory relation to nature - the contradictions we still live by.

After 1300, the socioecology of European feudalism headed toward crisis. Landlord revenues contracted, and peasant revolts, famine, and disease became increasingly frequent (Hilton 1973; Federici 2004). "Feudalism, as a social system no less than a system of production, was in crisis" (Moore 2002, 303). The fundamental problem was that lord-peasant relations, as well as Europe's wheat and livestock agricultural complex, were incompatible with agricultural sustainability. All productivity gains were appropriated by the lords of the land away from the soil and producers. Yet even amidst degradation and declining productivity, further population increases and conversion of marginal land remained the only means of increasing the surplus (Moore 2002, 303306). This is what Wallerstein $(1974,35)$ termed feudalism's "socio-physical conjuncture", a socioecological contradiction setting the stage for systemic crisis.

Yet it was environmental history that turned contradiction into "full-fledged crisis" (Moore 2002, 306). The Little Ice Age brought a "conjuncture of unfavorable weather and agrarian recession that produced increasingly severe and widespread famine" and "a dietary regime that virtually guaranteed epidemic disease" (Moore 2002, 306). That guarantee was realized in 1348 with the arrival of the Black Death. The catastrophic effect for the feudal system was to overturn the high labor-to-land ratio that had enabled lords to maximize surplus extraction from limited land without productivity gains (Moore 2002, 306-307). Lords now faced an inverted labor-to-land ratio that diminished incomes and empowered the peasantry (Federici 2004). In Western Europe the effort to reinstitute feudal class relations was thwarted by this numerically reduced but thus empowered peasantry. It was the Black Death that "signed feudalism's death warrant and favored a capitalist rather than 'tributary' solution to Europe's crisis" (Moore 2002, 
306).

The combined effect of environmental degradation, agrarian recession, climate, disease, and class struggle was to make an internal resolution through feudal compromise unlikely, and an external fix through different means an increasing necessity (Moore 2002, 308). As Wallerstein $(1974,24)$ argued, "the only solution" acceptable to Europe's ruling classes was to significantly expand the material resource base through geographic expansion. Part of this becoming necessity of an external fix was that formerly divided classes - seigneurs, states, city-state capitalists - began to consolidate as a historical bloc, to borrow a Gramscian phrase, in favor of expansion. Geography was also an enabling factor. Europe's highly fragmented political geography, manifest most importantly in the inability of any one ruler to establish a continental empire, created competitive states with no holds barred on expansion. Europe was a fragmented continent at an impasse, poised to reorient beyond its bounds (Moore 2002, 310-313).

The major import of Moore's analysis is to identify in feudal crisis the contradictions that capital's reorganization of nature had to resolve, only to forever shift and expand. But there is a second reason for reconsidering feudal crisis today. Feudal crisis was epochal, it could not be resolved within feudal modes of organizing nature. We are again arriving at such an impasse, an epochal crisis of capital as a mode of organizing nature. However, before jumping ahead to contemporary crisis, we need to first turn to the historical-geography of capital's contradictory eco-relations.

\section{The Commodity Frontier and the Transition to Capital}

Resolution of feudal crisis during the long 16th century (1450-1640) was fueled by expansion, but by a mode of expansion fundamentally different from that of the feudal era. Expansion was now driven not by population but rather by an ascendant logic of production for exchange (Moore 2007, 13). Moore calls this new mode of expansion the "commodity frontier", and it is through this conceptual frame that his account of transition unfolds.

Commodity frontier names the foundational concept of the world-ecology perspective (Moore 2007, 10-19). Its most general claims about capitalist transition are contained in its constitutive terms. 'Frontier' alerts us to the importance of geographical expansion to transition. 'Commodity' suggests not simple plunder or self-sufficient settler agriculture, but production for exchange. Combined these terms speak to the expansionary movement of production for exchange, the subordination of external ecologies to commodity production. Moore structures his narrative around silver (2010b) and sugar (2009; 2010a), commodities long recognized as crucial to capitalist transition, but one of his most important contributions is to show how these top-of-the-pyramid commodities necessitated, and are unthinkable without, the pioneering of a vast supporting cast of other frontiers (2010c; 2010d), particularly the forest and human labor power frontiers (Moore 2007, 16).

The commodity frontier unfolds through a place-process dialectic, referring "simultaneously to a certain kind of socio-spatial movement and to a certain kind of place" (Moore 2007, 13). The die for this place-process dialectic is cast by feudalism's socioecological contradictions. We are familiar with the process. Feudalism's insolvable crises drive a search for an external fix. The frontier-as-place also emerges in contradistinction to feudalism, as antithetical to its permeated socioecologies and empowered peasantries. The frontier-as-place must abound in ecological wealth and lack barriers to appropriation. At such sites the commodity frontier can materialize through the reorganization of ecological abundance - cheaply extracted timber, soil, labor 
power - around primary production. This is the first moment of the commodity frontier. Moore $(2009 ; 2010 a)$ fleshes it out historically through analysis of commodity frontier buildup along the metallurgy and mining frontier of central Europe and the sugar frontier of Maderia during the long 14th century, which he argues were "at the heart of an emergent and specifically capitalist configuration of nature-society relations" (Moore 2007, 69). The key point in both instances is that local abundance, forests in particular, is subordinated to commodity production. Yet like the felling of the forest it demands, the commodity frontier also comes crashing down.

The second moment of the commodity frontier dialectic - exhaustion - issues directly from its first. As noted, commodity frontiers materialize at sites where ecological abundance is reorganized around commodity production. This ensures a "yield honeymoon" (Moore 2010e, 400), but this is a union that cannot last. Forests are rapidly felled with conservation only an after thought. Slaves are worked to death for short-term profit maximization. Soil is stripped as long as greener-fields are on the horizon. The result is exhaustion, a term that refers not to environmental collapse, but the collapse of capital's crucial criteria: profitability. I want to call attention to how Moore's concept of exhaustion captures a critical point often missed by scholars of environmental transformation. On the commodity frontier, and more broadly within the capital-nature nexus, scarcity and degradation are never absolute but always relative to profitability. Trees remain, but it becomes ever more costly to subordinate them to commodity production. Once profitable frontiers turn progressively and then decidedly costly. This "exhaustion from below" is paired with "competition from above" (Moore 2007, 20). Specific commodity frontiers must compete with other frontiers and the lure of greener pastures. Moore examines how this paired dynamic gives rise to "sequential overexploitation" (Gadgil and Guha 1992) of ever-larger frontiers. From Central Europe metallurgy moves to the abundant forests of Sweden (Moore 2007; 2010c; 2010d) ; silver relocates to Potosi's mother lode and mita (Moore 2010b); from the dwindling forests of Madeira (Moore 2009; 2010a) the sugar frontier shifts to Brazil (Moore 2007). The logic of the commodity frontier is the logic of the drive-thru: get it and go.

Yet understanding the constitutive role of the commodity frontier for capitalist transition also requires shifting focus to the flow of frontier commodities back into the European core (Moore 2010c; 2010d). It is the crystallizations of frontier ecological wealth in commodity form that provide the steroidal supplement enabling the European core to internally intensify and further subordinate peripheral ecologies. To take one early example, Moore (2007, 76) follows Wallerstein (1974) in arguing that the silver of Central Europe arrived at the perfect time to lubricate an economy lacking sound money, providing collective confidence in production for exchange. Its most important impact was to draw Polish and Baltic landlords into a cash-based system of agricultural production for exchange with the core cities of Western Europe, thus "providing a significant share of the nutritional needs of urbanites in those very places where capital was being rapidly accumulated" (Moore 2007, 78). This supplement represents the initial and continually reinforcing wedge rifting town and country, the metabolic motor behind the division of labor.

The transition debate will continue. What is important here is that Moore's rephrasing of the question opens new horizons on capital's relation to nature. The critical point is this. Creative annihilation of ecological wealth along the commodity frontier is not a derivative consequence of a preformed capitalism but rather the constitutive materio-relational matrix through which capital as mode of organizing nature emerges. Commodity frontiers drove and wove capital's 
world-ecology, a point with major implications for our theories of capital's eco-logic.

\section{Theoretical Elaborations : From Value-Form to Value-Relations}

As noted above, the dialogue between capital-as-history and capital-as-theory - between its constitutive eco-relations and a re-grounded theory of its eco-logic - has been too muted. Moore (2010e; 2011a; 2014a; 2014b; 2014c; 2014d) radically advances the conversation by using the view from the commodity frontier to reconceptualize the core of critical economy: value theory. He urges us to turn from the value-form (i. e. the commodity) to the constitutive value-relations that enable that form to steer a whole civilization.

\section{Value as the Relational Hub of the World-Ecological Ensemble}

Marx's value theory is at the center of his critical theory, but marginal within the geographies of nature literature. One reason is that value theory is seen as anti-ecological, a view resting on two misinterpretations. First, it is common to mistake Marx's value theory for Smith and Ricardo's labor theory of value (Karatani 2003). For example, Cronon (1991, 149-151) criticizes Marxian value theory for failing to account for the natural wealth that made Chicago. This is a great point, but it is not a critique of Marx, who recognized that land and labor were the origins of all wealth (Foster 2000). A second common error is to mistake Marx's critique for endorsement, a grave error with bitter consequences. Value theory is not an embrace of an antiecological worldview, but discovery of the eco-logic through which capital organizes nature. For this reason, Robertson and Wainwright $(2013,11)$ call on geographers to return to value, the "headwaters" for any radical critique of capital's relation with nature. It is from these headwaters that Moore launches his theoretical elaboration of the historical analysis described above. For Moore, Marx's value theory is eminently post-Cartesian, but its implicit ecological critique must be rendered explicit by moving from a narrow focus on the commodity (i. e. value-form) to a broader view of that form's constitutive value-relations: from value as economic moment to value as relational hub of the world-ecological ensemble (Moore 2014a; 2014b; 2014d).

Our first move is to format history into value-theoretic terms. Moore (2014a: 20) asks us to conceptualize value's emergence as a transition from land to labor productivity. Recall that feudalism was centered on land productivity - the squeezing of surplus from limited land with minimal concern or hope for gains in labor productivity. In great contrast, capital's only valuemetric is labor productivity. Moore questions the process behind this transition, and answers via the commodity frontier. Cheaply appropriated abundance increases labor productivity at the frontier and in the core. But it does more than that. Cheap Nature becomes not a onetime fix, but rather the constitutive outside on which a whole civilization becomes fixated. It orients capitalist civilization towards an endless project of value-ing the world.

Based on his value-theoretical rendering of the commodity frontier, Moore (2014b) reconceptualizes value as a simplifying inner value-metric and expansive outer value-relations with the aid of two dialectical distinctions. The first - labor and work - describes the bifurcated distinction that capital makes between all the forms of energy transforming activity that enter its circuitry. Labor refers only to the small portion of all human activity spent in commodity production. It is this singular corner of activity that capital values. Work refers to all of the vast energy converted by human and extra-human agents into the matrix that underpins labor but does not enter its value-metric. Whether the activity in question is 
photosynthesis or plumbing, pregnancy or piggeries, capital's value-metric neatly divides it into labor and work, absolutely valuing the former and absolutely devaluing the latter (Moore 2014b). The fundamental contradiction here is that value production is underpinned by a vast socioecology of unpaid work that is not valued. Moore is certainly not the first to recognize that vast reserves of unpaid work go unvalued by capital but are necessary to value production. Feminists have long made the unpaid work of 'social reproduction' a basis for critique. Ecological economists have brought attention to the importance of ecosystem services to economy. What Moore shows is that, from the vantage of capital's inner value-metric, all noncommodity producing activity is homogenously devalued as work and that labor and work are mutually constituted and reciprocally determined, thus pointing to work-labor as framework for historical investigation.

“... the historical condition of socially necessary labor-time is socially necessary unpaid work. This observation opens a vista on capitalism as a contradictory unity of production and reproduction that crosses the Cartesian boundary. The crucial divide is between the zone of paid work ... and the zone of unpaid work" (Moore 2014b, 9).

The "crucial divide" is between capital's fictitious isolation of two interdependent circuits: a narrow circuit of exploitation and a vast circuit of appropriation. Exploitation names the subordination of human activity to the demands of abstract social labor in commodity production. Appropriation names the vast repertoire of "extra-economic processes to identify, secure, and channel unpaid work outside the commodity system into the circuit of capital" (Moore 2014a, 7). The narrow zone of intensive economic exploitation is fundamentally predicated on a massive zone of extensive ecological appropriation. Scholars have noted that unpaid work underpins labor. However, by deemphasizing the value-relations that determine socially necessary labor time, they have been unable to identify the socioecological relations through which work-labor and appropriation-exploitation are reciprocally determined.

Reframing value as a "contradictory unity" between exploitation and appropriation is a great leap forward for understanding how the contradictory unity between capital and nature works. Put simply, value bifurcates the world into two types of activity; one paid for, the other not. The key is that, even though work is devalued, profitability pivots on high levels of cheap appropriation relative to costly exploitation. This is an important corrective. Even in Smith's (1984) production of nature thesis, or his conceptualization of nature as a new accumulation strategy (2007), there is an argument that nature is increasingly commodified under capital. This is true, as far as it goes. However, commodification of everything is what capital needs but cannot have. Appropriation is an accumulation strategy, but a strategy only effective "to the degree that it controls and channels, but does not immediately capitalize, the reproduction of life-making capacities for the benefit of accumulation" (Moore 2014b, 12). Capital must have its work for nothing and nature for free, and that is why it is in dire straits today. That point will be explored later. First, however, we need to attend to how the praxis of appropriation even more fundamentally reshapes value theory.

\section{Abstract Social Nature and the Praxis of Appropriation}

As noted earlier, in later commentaries on the production of nature, Neil Smith (2008: 2011) repeatedly asserted the need to examine the historical process through which nature was 
ideologically cleaved from society. Moore provides a powerful answer to this question by employing his enriched value theory to ground an argument for why capital needs abstract nature. Rather than isolating ideology, power-knowledge or other so-called superstructural elements from the economic base, Moore frames the abstraction of nature as immanent to the rise of value, thus transforming value into the relational bond that transcends any basesuperstructure divide.

For Moore (2014b), the rise and consolidation of capitalism during the early modern period cannot be separated from the practices that made vast bundles of Cheap Nature appropriable. "Early capitalism's landscape transformations, in their epoch-making totality, were unthinkable without new ways of mapping space, controlling time, and cataloguing external nature" (Moore 2014b, 7). This suggests that value is no mere economic moment, but rather a civilizational strategy of making nature legible and appropriable. To move toward seeing the appropriation of Cheap Nature as a civilizational strategy, Moore (2014a; 2014b) borrows Mumford's (1934) concept of 'technics' to open a perspective on capital, nature and power as a unitary whole. He argues that our inability to see capital as civilizational technics has caused us to mistake the industrial revolution for capital's genesis, and also hidden the ways in which capital transcends any basesuperstructure divide. We need to interrogate capital not as a narrow economic system but as a modern civilizational technics predicated on real abstractions, abstractions that matter, abstractions that value.

Moore (2014b) provides us with another dialectical distinction crucial to rethinking naturecapital relations. He pairs abstract social labor, the rendering of concrete human activity into equivalent hands-in-motion in commodity production, with abstract social nature, an interlinked process of abstraction in the zone of appropriation. Abstract social nature references "the family of processes through which capitalists and state-machineries map, identify, quantify, measure, and code human and extra-human natures in service to capital accumulation" (Moore 2014b, 12). It thus refers to the broad processes through which human and extra-human work is transformed into Nature in general. The important point is that abstract social nature is immanent to the emergence of capital's constitutive value-relations. Capital does not just find nature, it actively produces a world ordered up for calculation and appropriation. It must revolutionize our "conceptions of the world", to borrow a term from Gramsci (Wainwright 2010b), through a praxis of transforming time and space. There is, thus, a second and interlinked moment involved in the transition from labor to land productivity. This is the drive to produce a concept of Nature abstracted from social integument.

Moore's reworking of value is a critical contribution to overcoming a base-superstructure divide that places value on economic terrain and power on political terrain. However, I want to offer a critique aimed at pushing world-ecology towards more thorough transgression. Moore's recasting of capital as technics is revolutionary. However, focusing on the technical moment risks excluding the morals, politics - and indeed values - that structure nature's production. Earlier I noted that world-ecology provides a framework for enriching Gramscian political ecology. Here I want to point out that a Gramscian turn could be equally productive for worldecology. There is a great opportunity to enhance Moore's critical excavation of value-relations by further emphasizing the constitutive role of the ethico-political, a central thread in Gramsci's historical materialism (Mann 2009). Abstract social nature pushes world-ecology in the direction of a historical materialism in which ideas matter. However, as Mann (2009) points out, it is equally important to advance a historical materialism in which the ethico-political — the terrain 
of Right - is recognized as ecological driver, as well as basis of hegemony and opposition. The key point is this. Value is constituted by a technics of abstraction, but that technics is also constituted by appeals to Right. It is a civilizational project that casts itself as bearer of Right in order to achieve world-ecological hegemony over the production of nature. Only an ethicopolitically infused historical materialism can identify how nature happens and how hegemony makes and is made by world-ecology. Such an approach to the ensemble of relations requires a more integral historical materialism than has been on offer in world-ecology research. A key task for the future is to introduce Gramsci to world-ecology in order to understand the making and unmaking of capital's world-ecological hegemony.

\section{Critical Diagnosis: The End of Cheap Nature and the Struggle over Value}

Here we consider how the world-ecological perspective sharpens our understanding of crisis and politics - what is happening, what is to be done. For Moore (2010e; 2014c), peak oil, climate change and financialization are all manifestations of the same world-historical event, the "end of the road" for capital's only viable accumulation strategy, appropriating Cheap Nature. The salient fact is, as always, not absolute resource scarcity or environmental degradation, but unprofitability. Remaining reserves of uncapitalized nature offer an insufficient basis for another revolution of productivity and profitability. It is the becoming dear of our daily bread that Moore (2014d) identifies as a key site for translating world-ecology into political struggle.

\section{The End of Nature (As Capital Knew It)}

Moore $(2014 \mathrm{c}$; 2014d) provides a broad reinterpretation of world-ecological history centered on the revolutions of productivity and exhaustion behind the rise and fall of long waves of accumulation and world-hegemony. The basic argument is that revolutions in productivity are revolutions of cheapening inputs, but that frontiers of uncapitalized nature sufficient to revolutionizing the mass of value-in-motion are no longer on any horizon. It's the end of nature, or at least the end of nature as capital knew it.

Looking back at the commodity frontier through the lens of value-relations suggests that, during the pioneering phase, there is a high rate of appropriation relative to exploitation. However, as a frontier tends toward exhaustion, that ratio is inverted. Costly exploitation begins to overtake cheap appropriation. From this embryonic analysis, as well as further historical application, Moore (2014c) conceives a broad framework for interpreting world-ecological accumulation cycles that, as he suggests, has parallels with Marx's overlooked conceptualization of underproduction crises. For Marx, underproduction crises were a result of the tendency for the technological capacity of fixed capital to outstrip capital's production of raw inputs. Today, such a notion of crises is forgotten, such that we think of all crises as crises of overaccumulation. However, before the industrial revolution, the dominant crisis for capital was underproduction. Capital was constantly outstripping resource supplies and searching for new frontiers. The industrial revolution opened up a whole new vast frontier that pushed underproduction crises out of mind, but they never disappeared. Frontiers have continued to be exhausted and profitability has continued to be cyclically fettered by a lack of cheap inputs. Indeed, for Moore (2014d), there is an essential link between underproduction and overaccumulation, since it is a lack of cheap inputs that limits profitable investment opportunities. This is, as we shall see, precisely the state of things today. But we first to need to 
further clarify the capital-nature relations that underpin world-ecological crises.

It is the rise and fall of the Four Cheaps - cheap food, labor-power, energy and raw materials - through agricultural revolution and exhaustion that provides the key site for theorizing cycles of accumulation and crisis (Moore 2010e; 2014c; 2014d). The Four Cheaps describes the essential inputs that capital must cheaply appropriate if it is to be profitable. The reason that agriculture is so important is that cheap food revolutions are critical to lowering the cost of labor power and advancing labor productivity. The problem for capital is that the cost of food must be cyclically and dramatically cheapened in order to outrun exhaustion and initiate a new round of accumulation. For Moore (2010e), all long waves of accumulation and world-hegemony are enabled by such agricultural revolutions. Dutch hegemony was predicated on high-value agriculture commodity production. Likewise, the British claimed world hegemony from the Dutch through major revolutions in agriculture, then maintained it by turning America into its breadbasket. Later the United States claimed world hegemony through petro-farming. Each of these revolutions pioneered a new mode of agricultural production that qualitatively and quantitatively revolutionized its predecessor by drawing on vast frontiers to supply the proletariat with cheap food.

Capitalist crises demand new frontiers, but what happens when agricultural frontiers are not forthcoming? For Moore (2014d), the answer to that question is found in a critical examination of the relation between agricultural non-revolution and neoliberalism. In contrast to the large literature in geography on the consequences of neoliberalizing nature (e.g. Heynen et al. 2007), Moore reads neoliberalism as not only acting on and through nature but as a mode of organizing nature that is called into being by former modes of organizing world-ecology. The essential precursor to neoliberalism is the failure of bio-technology to produce an agricultural revolution sufficient to revolutionizing labor productivity and capital accumulation. This failure gives rise to various one-time fixes aimed at cheapening food through primitive accumulation, including wage repression, the shift to the global factory, enclosure and proletarianization, the influx of women into the workforce and forced underconsumption (Moore 2014d). The effect is to temporarily defer crisis by drawing on cheapened land, food and labor. Neoliberalism is widely acknowledged to be an accumulation strategy predicated on taking first and making second (e.g. Harvey 2005). What Moore gives is a solid account of why taking has become capital's accumulation strategy and also an account of how that strategy is faltering. According to Moore (2014d), neoliberalism's signal crisis came in 2003 as food and other commodity prices began to quickly climb. What this signals is entry into an era of "post peak appropriation" in which Cheap Nature is now insufficient to the demands of the commodity circuit.

In addition to the exhaustion of nature as frontier tap, the production of surplus value is now also increasingly troubled by capital's long practiced strategy of using nature as sink, as limitless wastebasket (Moore 2014d). Waste frontiers - the spaces of internal externalities - have allowed capital to use nature as sink with little regard for local conditions. Now, however, formerly localized waste frontiers have congealed into a global waste frontier that offers no quarter. Capital is increasingly forced to negotiate with its prior waste, environmental degradations wishfully left behind. Moore (2014d) uses the term "negative-value" to describe how past degradations of the web of life are now inhibiting the production of surplus value. This term names "the accumulation of limits to capital in the web of life that are now fettering the restoration of the 'Four Cheaps': food, labor-power, energy and raw materials" (Moore 2014d, 11). Particularly problematic manifestations of negative-value are climate change and 
superweeds, issues materializing at the very moment that capitalist agriculture finds a frontierless playing field.

The crisis of neoliberalism signals the end of capital's cheap nature strategy: the culmination of a civilizational strategy that has shaped the production of nature for five centuries. We are entering an epochal crisis in which climate change, economic stagnation and social upheaval are but signs of something more fundamental, the twilight of the Capitalocene. The upshot is that we face the unraveling of capital's mode of organizing nature. An alternative organization of the production of nature has never been so critical.

\section{Value, It's What's For Dinner: Toward An Ontological Politics of Value}

In Uneven Development, Smith (1984) asked two fundamental questions. The first pertained to the historical-geography of capital, the second to its survival. Research under the worldecological banner has given us profound answers to both. The historical-geography of capital is the progressive advance of the commodity frontier. The survival of capital is predicated on appropriating more than it exploits. These are absolutely critical enrichments of the production of nature thesis. Yet Smith's production of nature thesis had obvious political intent from its conception. Moore has only recently taken up the task of translating the world-ecological worldview into politics.

The end of Cheap Nature pushes Moore to explore the "relationship between the breakdown of capitalism's technological model and the rise of a new ontological politics that challenges not just the terms of productivism but its very logic" (Moore 2014d, 19). This new "ontological politics" can be found in numerous social movements challenging not only capital's distribution or consequences but the very logic of placing the substance of life at the service of surplus value. Here, then, we move from particular battles over the production of nature to a struggle over the headwater from which they flow: capital's inner value-metric and the constitutive value-relations it demands. This is a battle to redefine the values that will structure the production of nature in a socialist world-ecology.

The centrality of food and agriculture historically, and the prevalence of struggles surrounding these issues today, leads Moore (2014d) to focus on this particular constellation of paid and unpaid work as central to class struggle going forward. Food and agriculture have always been political. The difference today is that neoliberalism's strategies of plunder and toxification have elevated them to primary issue (Moore 2014d). To be sure, opposition is uneven. In the Global North opposition often takes the form of reclaiming healthy food and agriculture through urban gardening and consumer politics. In the Global South, opposition is advanced through struggles over land and food sovereignty. The uneven development of struggles over food should not be minimized. But neither should the similarities. What often links struggles over food across uneven geographies is that they center on alternative valuations and a radically different ontology of food (Moore 2014d: 23). The critical task, as Moore (2014d, 24) acknowledges, is to begin to translate these alternative valuations into a new hegemony. Here, then, ontological politics meets with an ethico-political moment of advancing claims of Right. And it is here, again, that the world-ecology perspective could gain analytical and political purchase through an engagement with Gramsci's ethico-politically infused historical materialism and its problematic of hegemony. 


\section{Conclusion: Rethinking Geographies of Nature from a World-Ecology Perspective}

Geographies of nature names a field of revolutionary knowledge production. One of its most important contributions is to have considerably advanced our knowledge of how the contradictory unity of capital's relation to nature plays out. Yet there has been a reluctance to see nature as totality or to deal with world-history by trekking back and forth over the tightrope between history and theory. The fate of the production of nature thesis is illustrative. Neil Smith (1984) broke open new horizons with a jarring concept and an account of how the production of nature probably happened. But neither Smith nor later applications of his thesis have sought to enrich that account from its foundations.

This introduction to world-ecology has shown what is to be gained by pushing the production of nature onto the terrain of world-history. By dancing back and forth between history and theory, the whole and the parts, the world-ecological perspective provides us with a powerful, to borrow a term from Gramsci, "conception of the world" (Wainwright 2010b), that can substantially enrich attempts to rethink geographies of nature. First, Moore's work provides a powerful response to Harvey's $(2014,250)$ plea to "more fully understand how the contradictory unity between capital and nature works" by identifying how capital consolidates, survives and why it is in trouble today. Capital is born of external fix, it survives by appropriating faster than it exploits. It is in trouble today because it has annihilated Cheap Nature. At the center of this narrative is value, a civilizational strategy and technics of abstracting the world as standing reserve. It is the end of the frontier today that makes value the key site of breakdown and opposition. There is a great opportunity to engage the world-ecology perspective by situating our work in the conceptual and methodological framework it provides. Earlier I called attention to Ekers and Loftus' (2012) call for "revitalizing" the production of nature thesis through further attention to concrete labor. The world-ecology perspective gives us the framework we need to situate all work within world-ecological ensemble of relations.

Yet there remains a pressing need to fortify the analytical and political purchase of the worldecology perspective by bringing it into dialogue with Gramsci's ethico-politically infused historical materialism (Mann 2009). The world-ecology perspective was initially advanced through a historical materialism that many geographers, Moore included, would recognize as somewhat one-sided. The main thrust and sheer scope of the project required bracketing questions of culture, discourse, power and ideology. The under-emphasis on such issues explains, in part, why human geographers have been slow to engage with the world-ecology perspective. However, Moore (2014a; 2014b; 2014d) and many fellow travelers are now working to give a more fulsome account of the world-ecological production of nature through an expanded historical materialism, one that recognizes the importance of power, culture, knowledge and ideology while crucially retaining value as unitary center of explanation and target of opposition. There is an important need and opportunity here to extend Moore's focus on technics and ontological politics to the ethico-political both historically and today. We need to identify how worldecological hegemony works if we are to take it by the helm.

\section{Notes}

1. The term "geographies of nature" [shizen no chirigaku] is borrowed from Asano and Nakashima's (2013) review of the Anglophone geographical literature on nature. Although "geographies of nature" is not frequently used in 
Anglophone geography, a wide-ranging literature does indeed take nature as its problematic. The initial aim of this literature was to demonstrate that nature was socially produced/constructed by deconstructing nature and society dualisms and advancing a post-Cartesian worldview. Important statements include Smith (1984), Harvey (1996), and Castree and Braun (2001). More recently, geographical work on nature has become indistinguishable from a broad political ecology of the left that has a large wing within geography but extends well beyond it. Major statements include Robbins (2004) and Heynen et al. (2006).

2. The world-ecology perspective has been pioneered by geographer Jason W. Moore, but the phrase "world ecology" first appears in Wallerstein $(1974,44)$. Drawing considerable inspiration from Wallerstein's suggestive term and broader approach, Moore has combined world-systems analysis with environmental history, left political ecology and Marxian geography to formulate a revolutionary approach to capital's ecology. He has published voluminously on the world-ecology perspective, but a broad overview of the perspective remains missing. The best overviews are Moore (2007; 2011a; forthcoming). Moore's many publications are available at his website. http://www. jasonwmoore.com/Essays. html

\section{References}

Asano, T. and Nakashima, K. (2013) Geographies of nature [Shizen no chirigaku], in Social geography of nature. eds T. Asano and K. Nakashima, 13-37, Otsu: Kaiseisha Press. (in Japanese)

Castree, N. and Braun, B. eds. (2001) Social nature: theory, practice, and politics. Oxford: Blackwell.

Cronon, W. (1991) Nature's metropolis: Chicago and the great west. New York: Norton.

Ekers, M., and Loftus, A. (2012) Revitalizing the production of nature thesis. Progress in Human Geography 37: 234 -252 .

Ekers, M., Hart, G., Kipfer, S., \& Loftus, A. (2013) Gramsci: space, nature, politics. Chichester: John Wiley \& Sons. Federici, S. (2004). Caliban and the witch. New York: Autonomedia.

Foster, J. B. (2000) Marx's ecology: materialism and nature. New York: Monthly Review Press.

Gadgil, M., and Guha, R. (1992) This fissured land: an ecological history of India. Berkeley: University of California Press.

Harvey, D. (1996) Justice, nature and the geography of difference. Oxford: Blackwell.

Harvey, D. (2005). A brief history of neoliberalism. Oxford: Oxford University Press.

Harvey, D. (2014) Seventeen contradictions and the end of capitalism. London: Profile Books.

Heynen, N., Kaika, M., \& Swyngedouw, E. (2006) In the nature of cities: urban political ecology and the politics of urban metabolism. London: Routledge.

Heynen, N. McCarthy, J. Prudham, S. \& Robbins, P. (2007) Neoliberal environments: false promises and unnatural consequences. London: Routledge.

Hilton, R. H. (1973) Bond men made free: medieval peasant movements and the English rising of 1381. New York: Viking.

Karatani, K. (2003) Transcritique on Kant and Marx. Cambridge, Mass: MIT Press.

Labban, M. (2011) History, space and nature: building theory from the exception, New Political Economy 16: 253259.

Mann, G. (2009) Should political ecology be Marxist? A case for Gramsci's historical materialism, Geoforum 40: $335-344$.

Moore, J. W. (2002) The crisis of feudalism: an environmental history, Organization E Environment 15: 296 -317.

Moore, J. W. (2003) The Modern World-System as environmental history? ecology and the rise of capitalism, Theory E Society 32: 307-377.

Moore, J. W. (2007) Ecology and the rise of capitalism. PhD Dissertation, Department of Geography, University of California - Berkeley.

Moore, J. W. (2009) Madeira, sugar, \& the conquest of nature in the 'first' sixteenth century, part I: from 'island of timber' to sugar revolution, 1420-1506, Review: A Journal of the Fernand Braudel Center 32: 1-46.

Moore, J. W. (2010a) Madeira, sugar, and the conquest of nature in the 'first' sixteenth century, part II: from local crisis to commodity frontier, 1506-1530, Review: A Journal of the Fernand Braudel Center 33: 1-24.

Moore, J. W. (2010b) 'This lofty mountain of silver could conquer the whole world': Potosí and the political ecology of underdevelopment, 1545-1800, Journal of Philosophical Economics 4: 58-103.

Moore, J. W. (2010c) 'Amsterdam is standing on Norway' part I: the alchemy of capital, empire and nature in the diaspora of silver, 1545-1648, Journal of Agrarian Change 10: 33-68.

Moore, J. W. (2010d) 'Amsterdam is standing on Norway' part II: the global North Atlantic in the ecological revolution of the long seventeenth century, Journal of Agrarian Change 10: 188-227.

Moore, J. W. (2010e) The end of the road ? agricultural revolutions in the capitalist world-ecology, 1450-2010, Journal of Agrarian Change 10: 389-413. 
Moore, J. W. (2011a) Ecology, capital, and the nature of our times: accumulation and crisis in the capitalist worldecology, Journal of World-Systems Research 17: 108-147.

Moore, J. W. (2011b) Transcending the metabolic rift: a theory of crises in the capitalist world-ecology, The Journal of Peasant Studies 38: 1-46

Moore, J. W. (2014a) The capitalocene part I: on the nature \& origins of our ecological crisis, Jason W. Moore, June 1, 2014, accessed June 10, 2014, http://www. jasonwmoore.com/Essays.html

Moore, J. W. (2014b) The capitalocene part II: abstract social nature and the limits to capital, Jason W. Moore, June 1, 2014, accessed June 10, 2014, http://www.jasonwmoore.com/Essays.html

Moore, J. W. (2014c) The end of Cheap Nature or: how I learned to stop worrying about 'the' environment and love the crisis of capitalism, in Structures of the World Political Economy and the Future of Global Conflict and Cooperation, eds. C. Suter and C. Chase-Dunn, 285-314, Berlin: LIT.

Moore, J. W. (2014d) Cheap food \& bad climate: from surplus value to negative-value in the capitalist world-ecology, Jason W. Moore, August 1, 2014, accessed August 8, 2014, http://www. jasonwmoore. com/Essays. html

Moore, J. W. (forthcoming). Ecology \& the accumulation of capital. London: Verso.

Mumford, L. (1934) Technics and civilization. New York: Harcourt, Brace and Co.

Robbins, P. (2004) Political ecology: a critical introduction. Malden, MA: Blackwell.

Robertson, M. and Wainwright, J. (2013) The value of nature to the state, Annals of the Association of American Geographers 103: 890-905.

Smith, N. (1984) Uneven development: nature, capital and the production of space. Oxford: Basil Blackwell.

Smith, N. (2007) Nature as an accumulation strategy, Socialist Register, 43: 1-36.

Smith, N. (2008) Afterword to the third edition, in Uneven development: nature, capital and the production of space. N. Smith, 239-266. Athens: The University of Georgia Press.

Smith, N. (2011) Uneven development redux, New Political Economy 16: 261-265.

Wainwright, J. (2010a) Was Gramsci a Marxist ? Rethinking Marxism, 22: 617-626.

Wainwright, J. (2010b). On Gramsci's 'conceptions of the world', Transactions of the Institute of British Geographers 35: $507-521$.

Wallerstein, I. (1974) The modern world system I: capitalist agriculture and the origins of the European world-economy in the sixteenth century. New York: Academic Press. 